\title{
Expansion of postpartum/postabortion contraception in Honduras
}

\author{
Ruth Medina \\ Population Council \\ Ricardo Vernon \\ Population Council \\ Irma Mendoza \\ Population Council \\ Claudia Aguilar \\ Population Council
}

Follow this and additional works at: https://knowledgecommons.popcouncil.org/departments_sbsr-rh

Part of the Demography, Population, and Ecology Commons, International Public Health Commons, Maternal and Child Health Commons, and the Public Health Education and Promotion Commons How does access to this work benefit you? Let us know!

\section{Recommended Citation}

Medina, Ruth, Ricardo Vernon, Irma Mendoza, and Claudia Aguilar. 2001. "Expansion of postpartum/ postabortion contraception in Honduras," FRONTIERS Final Report. Washington, DC: Population Council. 


\title{
Expansion of Postpartum / Postabortion Contraception in Honduras
}

\author{
Ruth Medina \\ Ricardo Vernon \\ Irma Mendoza \\ Claudia Aguilar \\ POPULATION COUNCIL
}

June 15, 2001

Expansion of Postpartum / Postabortion Contraception in Honduras. April 1, 1999 - June 30, 2001. This study was funded by the U.S. AGENCY FOR INTERNATIONAL DEVELOPMENT (USAID) under the terms of Cooperative Agreement Number HRNA-00-98-00012-00 and Subproject number 580113009 424. The opinions expressed herein are those of the authors and do not necessarily reflect the view of USAID. 


\section{SUMMARY}

In Honduras, 54 percent of deliveries are assisted by medical staff and 39 percent of deliveries take place at Ministry of Health of Honduras (MOH) health centers or hospitals. Although the unmet need for family planning services is relatively high $(11 \%$ of women) and family planning helps protect mothers' and children's health, hospitals in Honduras rarely offer postpartum/postabortion contraceptive services.

Between 1996 and 1999, the Ministry of Health and the Population Council's INOPAL III Project tested the acceptability of postpartum/postabortion contraception at the Escuela Hospital, the largest in the country. The project showed that more than 30 percent of the women seen for a delivery or a complication due to abortion, were interested in adopting a contraceptive method prior to discharge from the hospital. Given the success of the project, the MOH asked the Population Council's FRONTIERS Program for technical and financial support to extend those services to five additional hospitals in the country.

As a first step, a baseline situational analysis study was carried out in seven hospitals in order to detect needs and identify the hospitals in which postpartum/postabortion contraceptive services could be most easily introduced or strengthened. In the five hospitals selected, the results of the diagnostic study were presented, staff were trained, equipment, clinical and educational materials were provided, surveys were conducted, and quarterly meetings were held to analyze achievements and plan new activities.

The baseline diagnosis showed that a great demand existed for contraceptive methods before discharge from the hospital. Only 35 percent of the women who had given birth had planned the pregnancy, and close to one-half said they would have preferred to wait longer or not become pregnant. Seventeen percent were using a method of contraception when they became pregnant. Only 44 percent wished to become pregnant in the future, and 92 percent of these women wanted to space their next pregnancy for more than two years.

Important improvements were found for the four indicators used to evaluate the project: 1) the proportion of women who received information about contraceptive methods during their hospital stay increased from 43 percent to 87 percent; 2) the proportion of women who were offered a contraceptive method increased from 42 percent to 82 percent; 3 ) the proportion of women who received a contraceptive method during their stay increased from 10 percent to 33 percent; and finally, 4) the proportion of women who had delivered and wanted a method before leaving the hospital but did not receive it decreased from 41 percent to 7 percent. Among the women who had been treated for an abortion (close to $10 \%$ of those who had delivered), the results were even better: information increased from 17 percent to 85 percent; offering of methods increased in the same proportion; acceptance of methods increased from 13 percent to 54 percent; and unmet need decreased from 48 percent to 21 percent. In both cases, the 
main cause for unmet need was the impossibility of going through all the surgical sterilization procedures asked for prior to discharge from the hospital.

The main reasons for this success are attributed to the involvement of $\mathrm{MOH}$ managers in planning the activities and to the quarterly discussions of the monitoring surveys, which helped the providers focus their attention on the introduction and strengthening of services during an entire year. Finally, we recommend also training nurse auxiliaries in IUD insertion, since some hospitals care for an important proportion of deliveries. 


\section{TABLE OF CONTENTS}

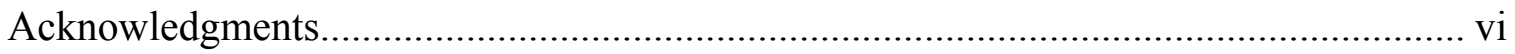

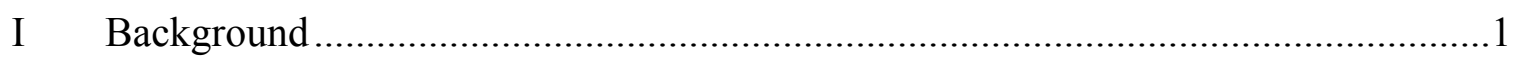

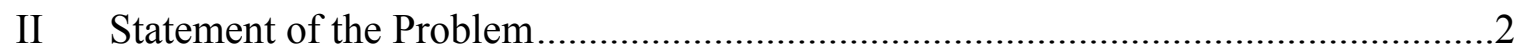

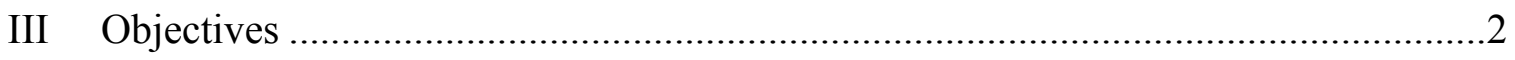

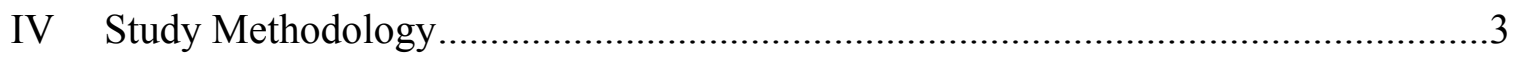

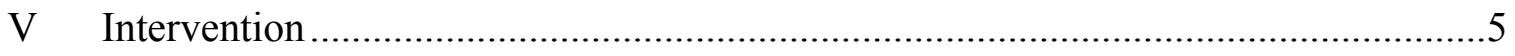

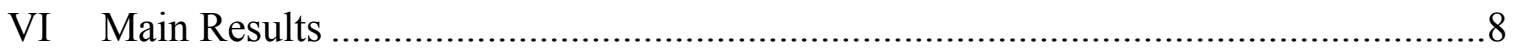

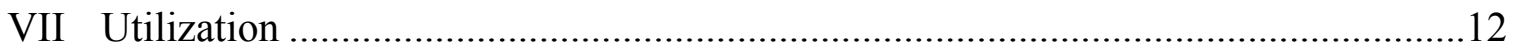

VIII Conclusions and Recommendations ...................................................................13

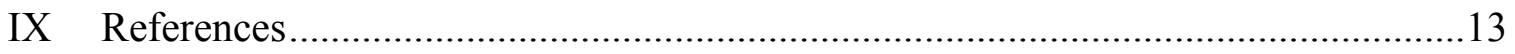

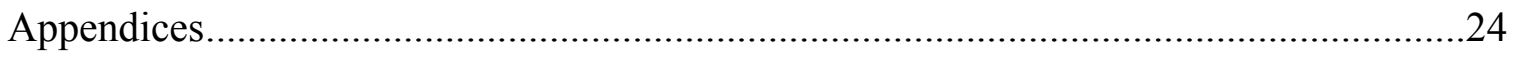




\section{LIST OF TABLES}

Table 1: Total number of women interviewed in postpartum and postabortion care, by hospital and type of survey

Table 2: $\quad$ Main characteristics and indicators of selected hospitals. Honduras 1999

Table 3: $\quad$ Number of interviews and observations conducted in the baseline situational analysis, by hospital and instrument used

Table 4: $\quad$ Family planning services available in the hospitals at the start of the study, according to hospital and type of service

Table 5: Indicators of post-partum family planning service delivery, according to survey

Table 6: $\quad$ Proportion of women who were attended for an obstetric event and who received a contraceptive method, by method and period. Service statistics of participating hospitals

Table 7: $\quad$ Indicators of unmet need, according to survey

Table 8: $\quad$ Indicators of family planning service delivery and unmet need, according to hospital and date of follow-up

Table 9: Indicators of family planning service delivery in postabortion care, according to survey 


\title{
ABBREVIATIONS
}

\author{
AVSC: $\quad$ Association for Voluntary Surgical Contraception \\ ASHONPLAFA: Honduran Family Planning Association \\ IHSS: $\quad$ Honduran Social Security Institute \\ IUD: $\quad$ Intrauterine Device \\ MHC: $\quad$ Health Center with physician and dentist (known as CESAMO in \\ Honduras) \\ MOH: $\quad$ Ministry of Health of Honduras \\ RHC: $\quad$ Rural health center (Centro de Salud Rural, or known as CESAR in \\ Honduras) \\ VSC: $\quad$ Voluntary Surgical Contraception. \\ WHO: $\quad$ World Health Organization \\ USAID: $\quad$ United States Agency for International Development
}




\section{ACKNOWLEDGEMENTS}

This study was conducted with support from and in collaboration with:

Dr. Jorge Humberto Melendez, Head of the Maternal and Child Health Department of the Ministry of Health, and Dr. Ivo Flores, Head of the Attention to Women Department.

Health care providers in labor and birthing rooms, emergency, postpartum, gynecology and surgery departments of the following hospitals: Atlantida, Occidente, San Francisco, Dr. Enrique Aguilar Cerrato, and the maternity ward of the San Felipe General Hospital.

Dr. Mirta Ponce, Dr. Alonso Pintor, Dr. Rommel Carrasco, Abel de Jesus Cerrato and Dr. Cesar Banegas; Directors of the Atlantida, Occidente, Dr. Enrique Aguilar Cerrato, San Francisco, and the maternity ward of the San Felipe General Hospital, respectively.

We especially wish to thank the technical contacts in each hospital for their participation in the project and for the internal support they provided for the completion of the activities: Luz Barahona, Teresa Nuñez and Gloria Fiallos, nurses at the Atlantida Hospital; Dr. Gloria Fajardo at the Occidente Hospital; Sara Yanez, B.A. at the Dr. Enrique Aguilar Cerrato Hospital; Argelia Gallo, B.A. at the San Francisco Hospital; and Nolvia Rodriguez, B.A. at the maternity ward of the San Felipe General Hospital.

To the staff of USAID Honduras: Marianne Andersen, John Rogosh, Dick Montieth, Angel Coca, Meri Sinnit and Maricarmen Miranda. 


\section{BACKGROUND}

Each year, approximately 108 women in Honduras die due to complications during pregnancy, delivery or puerperium. Unplanned or unwanted pregnancies increase health risks: one in every eight maternal deaths is related to abortion complications (Ministry of Health, 1997). By eliminating unwanted pregnancies, up to 25 percent of maternal deaths could be avoided. Family planning can also prevent childhood deaths: a child that is born less than two years after his or her sibling is twice as likely to die than a child who is born two or more years after his/her sibling. By spacing children, up to 25 percent of children's deaths could be avoided (Shane, 1997).

According to the 1996 National Epidemiology and Family Health Survey (Ministry of Health et al., 1997), in Honduras 55.4 percent of married women between 15 and 44 years of age used a family planning method, and 11 percent of the women had unmet need for family planning services, since they were sexually active, fertile, did not want to have children, and did not use a contraceptive method.

A little more than one-half of the births in Honduras take place in hospitals. Institutional deliveries are a public health priority for the $\mathrm{MOH}$, so it is likely that the proportion of births attended at hospitals will continue growing in the future. Operations research has shown that when contraceptive methods are made available at hospitals, an important proportion of women who have had a birth ask for a method before discharge from the hospital. Studies also have shown that a higher proportion of women use a contraceptive method six months after delivery when they deliver in a hospital that offers postpartum contraceptive services. (Foreit et al., 1993). Other studies have demonstrated positive effects of postpartum contraception services on mothers' health (Family Health International, 1995).

Three operations research studies have demonstrated that both service providers and women accept postpartum/postabortion contraception in Honduras. During 1986-88, PROALMA and the Honduran Social Security Institute (IHSS) at San Pedro Sula, in collaboration with the Population Council INOPAL I project, tested the impact of promoting breastfeeding and family planning in the postpartum period, both at the hospital before discharge as well as during follow-up visits. The results showed that women exposed to the intervention were better informed about both topics. At six months postpartum, 68 percent of women in the experimental group were using a modern effective method, compared to 54 percent in the control group where the promotion had not been conducted. Exclusive breastfeeding at four months was 22 percent verses 12 percent in the control group, and 72 percent of mothers in the experimental group were breastfeeding at six months, compared to 57 percent in the control group (Chavez et al, 1986).

In 1989, the IHSS and the INOPAL II/Population Council project, tested a postpartum family planning model in which female sterilization, IUD, minipills and condoms were made available to women who had just delivered. Additionally, family planning counseling was provided during pre and post natal care, and women had two 
opportunities to receive a contraceptive method: before leaving the hospital and 40 days after delivery. The results showed that 25 percent of the women who had delivered chose a contraceptive method before discharge from the hospital and an additional 20 percent during their 40-day post-partum visit. The satisfaction with the services provided also increased considerably (Lopez-Canales et al, 1992).

Between 1996 and 1999, the Ministry of Health and the INOPAL III/Population Council project tested the acceptance of postpartum/postabortion contraception at the Escuela Hospital, which is the largest hospital in the country and attends approximately 30,000 obstetric events annually. The model tested included training of physicians, nurses, and nurse auxiliaries in family planning counseling and in contraceptive methodology, the provision of medical and educational materials and equipment, and the systematic offering of contraceptive methods to women hospitalized for delivery or an abortion. Close to 30 percent of the women asked for and received a contraceptive method before leaving the hospital (Medina et al, 1998).

\section{STATEMENT OF THE PROBLEM}

The problem this project approached was how to expand the postobstetric event family planning service delivery model previously tested and evaluated in the Escuela Hospital to other hospitals. This model consists of providing information to all women who will deliver or have just delivered, so that they may decide if they want to adopt a contraceptive method, which method and when, and offer and provide the methods so that women can act consequently.

\section{OBJECTIVES}

The general objective of this project was to increase access to quality contraceptive services after an obstetric event and reduce the unmet need for family planning. The specific objectives were:

- Conduct a diagnostic study of postpartum and postabortion contraceptive services provided at seven hospitals.

- According to the diagnosis, select the five hospitals with the most promising conditions and introduce or strengthen postpartum/postabortion contraceptive services, in accordance with Family Planning Service Delivery Guidelines in Honduras.

- Expand and evaluate the postpartum/postabortion contraceptive service delivery and promotion model tested in the Escuela Hospital, which includes increasing the range of contraceptive methods offered in each 
hospital, and information, counseling and provision of contraceptive methods to all women who want them.

\section{STUDY METHODOLOGY}

\subsection{Design}

To evaluate the impact of the postpartum/postabortion family planning model, a quasi-experimental design with quarterly measurements was used. This design is represented in the following diagram, where the Os are observations and the $\mathrm{X}$ is the intervention.

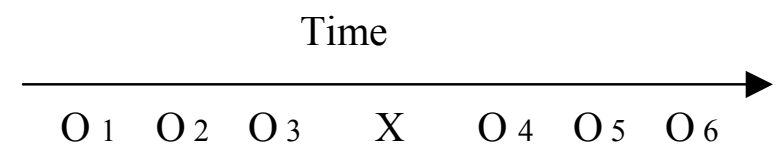

\subsection{Hypothesis}

The availability and systematic offering of counseling and family planning services to women in the postpartum or postabortion periods will decrease the unmet need for contraception and will increase the proportion of women who choose a contraceptive method before discharge from the hospital.

\subsection{Independent Variable}

The independent variable is the expansion of the postobstetric event services model, which consists of: a) training of staff in the promotion of family planning services and counseling of clients; b) training in contraceptive methodology; c) provision of materials and equipment; and d) supervision and monitoring of activities, as described in the following sections.

\subsection{Dependent Variables}

Postobstetric event contraception coverage: proportion of women who choose and receive a contraceptive method before leaving the hospital after a delivery or an abortion.

Information provided about family planning: proportion of women in the postpartum or postabortion periods who report having received family planning information during their stay in the hospital.

Offering of family planning methods: proportion of women in the postpartum or postabortion periods who report having been offered a contraceptive method before discharge from the hospital. 
Unmet need for postobstetric event contraception: proportion of women in the postpartum or postabortion periods who report having wanted a contraceptive method before leaving the hospital but did not receive a method.

\subsection{Sources of Information}

Contraceptive coverage was measured through service statistics, using as the denominator the women admitted to the hospital for delivery or for abortion complications, and as the numerator the women who received a contraceptive method. In addition, all the dependent variables were measured through periodic surveys, which had the following characteristics:

Baseline, midterm and endline hospital surveys: during these surveys, we interviewed all women who had been provided care for a postobstetric event during two consecutive weeks (including Saturdays and Sundays). They were applied before the women left the hospital and were voluntary. The interviews were made by hired interviewers who were trained in the use of the pre-coded questionnaire presented in Appendix 1. The surveys were applied in July 1999, September 2000, and March 2001. Table 1 shows that 474, 675 and 571 women in the post-partum period were interviewed in the baseline, midterm and endline surveys, respectively, as well as 24, 59 and 71 women in the postabortion period. As described in section 5.1, in the baseline diagnosis, eight different questionnaires were applied, five of which were used to interview directors and service providers, one to determine the hospital's resource inventory, and two to interview women in postpartum and postabortion care. Only the last two questionnaires were applied during the midterm and endline surveys.

Quarterly surveys in hospitals: these surveys only contained basic information that allowed hospital staff to observe and analyze the project's progress, and agree on and plan corrective actions and new interventions. The main function of these surveys was to maintain the hospital team's attention on the service introduction and service strengthening processes. Given that the data that these surveys yielded do not show different tendencies than the data from the baseline, midterm and endline surveys, and that the samples are considerably smaller, the data from these surveys are not presented in this report. Surveys were conducted in March, June and December 2000. Table 1 shows that an average of 238 women in postpartum care and 26 women in postabortion care, were interviewed during the three monitoring periods. Appendix 2 shows the questionnaires used to conduct the quarterly monitoring.

Service statistics: the following service statistics were collected every quarter, semester and year: number of deliveries, number of abortions, and number of contraceptive methods (sterilization, IUD, DMPA and condoms) provided to women after an obstetric event. The data were collected from the hospital statistics department and from the $\mathrm{Ob}-$ Gyn and puerperium wards. 


\section{DESCRIPTION OF THE INTERVENTION}

The following activities were implemented:

\subsection{Baseline Diagnostic Study and Selection of Hospitals}

The purpose of the initial diagnostic study was twofold: to obtain a baseline for the dependent variables, and to obtain information to identify the hospitals where it would be easiest to introduce or strengthen postpartum/postabortion contraceptive services.

The study took place in July 1999 in seven hospitals pre-selected by the Maternal and Child Health Department, using high maternal mortality rates in the hospitals' area of influence as the criteria for selecting them. The pre-selected hospitals were Atlantida (in La Ceiba), Del Sur (in Choluteca), Gabriela Alvarado (in Danli), San Felipe (in Tegucigalpa), Occidente (in Santa Rosa de Copan), San Francisco (in Juticalpa), and Enrique Aguilar Cerrato (in La Esperanza). Table 2 represents the hospitals' main characteristics. The number of Ob-Gyn beds varies between 18 and 39, except San Felipe Hospital, which has 60 beds. The hospital in La Esperanza attends less than 3,000 deliveries per year, the hospitals in Juticalpa and La Ceiba around 3,500 deliveries, the San Felipe hospital a little more than 5,000 deliveries and the hospital in Santa Rosa attends almost 6,000 deliveries per year. All have cesarean section rates below $20 \%$, as recommended by the $\mathrm{WHO}$, and the number of abortion complications treated are about 10 percent of number attended for deliveries.

Seven questionnaires were used in each of the participating hospitals in the baseline situational analysis, each to interview: 1) the hospital's Director; 2) the Head of the Gynecology and Obstetrics Department; 3) staff who work in Gynecology and Obstetrics; 4) staff who offer family planning services in outpatient services (where available); 5) the head of outpatient services and the head nurse of outpatient services where family planning services, prenatal care and postnatal care services are offered; 6) women hospitalized for delivery; and 7) women hospitalized for an abortion complication. In addition, an eighth instrument was used to conduct an inventory of equipment, materials and installations available and services offered at each hospital. Table 3 shows the total number of interviews conducted in each case.

The results of the initial diagnosis are presented in the sections 6.1 and 6.2. However, it is important to clarify at this stage that the baseline study showed that the hospitals in Choluteca and Danli had the least favorable conditions for the introduction of services. For this reason, these hospitals were excluded from the project.

A meeting was held in each hospital to present the results from the baseline situational analysis. All staff who provided Ob-Gyn and outpatient services attended the presentation. In addition, the hospital director presented statistical data on maternal mortality and other health indicators for the hospital's service area. Finally, the 
postobstetric care family planning services model developed in the Escuela Hospital was presented, and the staff was informed that the model would be replicated in each hospital.

\subsection{Training of Personnel}

In each hospital, all service delivery staff who provided services to women in the postpartum or postabortion period were selected for training, as well as service providers who worked in nearby health centers and who would counsel their prenatal care clients about the new postpartum family planning services at the hospital.

Physicians, nurses, nurse auxiliaries, social workers, and educators in the Ob-Gyn wards attended a 30-hour workshop on service promotion and counseling in family planning. Seven workshops were given (one in each of three hospitals and two in each of two hospitals) between December 1999 and April 2000. The following topics were reviewed in the workshops: 1) effective communication; 2) characteristics of good communication; 3) promotion, information, and counseling concepts; 4) a counselor's qualities and characteristics; 5) informed consent and informed choice; 6) orientation and counseling techniques; 7) counseling needs of special populations (adolescents, women in postpartum care, and women in postabortion care). The workshop included the use of informed consent forms for IUD insertion and for VSC, as well as the use of pamphlets and flipcharts to promote and provide family planning counseling. The training's contents were developed taking into account the Ministry of Health's service delivery guidelines. The training was given to 127 service providers in five hospitals and to 37 service providers from outlying health centers. On average, the participants improved their knowledge scores by 21 percent between the training's pre and posttests.

In a second phase, five courses on contraceptive methodology were given (one in each hospital) between April and July 2000. Each course lasted five days, divided in two parts: a theoretical workshop on contraceptive methodology, and postpartum/postabortion IUD insertion techniques. A total of 65 service providers (physicians and nurses) were certified in postpartum IUD insertion and 44 in postabortion IUD insertion. In addition, four Ob-Gyn physicians and one nurse were trained in minilap with sedation and local anesthesia. Each training was conducted in ASHONPLAFA, in Tegucigalpa, during one week.

\subsection{Equipment}

In order to facilitate the provision of postabortion care services, each hospital was provided with five IUD insertion equipment kits, which consist of: three uterine measurement probes, four speculums, a stainless steel container, a cup for antiseptic solution, a tray, a short curved Kelly clamp, a Kelley clamp for IUD removal, a Metzen Baum clamp, a straight Forester clamp, curved scissors, an IUD removal hook, and a tenaculum.

For postpartum IUD insertion (post-placenta, before leaving the hospital and abortions later than 12 weeks of gestation) each hospital was provided with $30-12$ inch 
smooth ring Forester clamps, $10-4.5$ by 1.5 inch large speculums, $20-12$ inch curved Kelley clamps for placenta, and $10-6$ ounce antiseptic solution cups.

Each hospital was also provided with a gynecological exam table. A special area of the Maternity ward at San Felipe Hospital was conditioned to guarantee the patients' privacy during postpartum IUD insertion, providing them with an additional metallic screen and gooseneck lamp.

\subsection{Establishment of a Referral System}

In all hospitals, except Atlantida in La Ceiba, nurse auxiliaries, nurses and general physicians from health center in the hospitals' area of influence were invited to participate in the family planning counseling workshops. Each health center was also provided with flipcharts so that they could provide family planning counseling during prenatal care visits, such that the women would arrive at the hospitals prepared to make an informed choice of a postpartum family planning methods.

\subsection{Provision of Printed and Audiovisual Educational Material}

In order to facilitate promotion, information and counseling activities, each hospital was provided with the following printed material: 15 flipcharts with "Basic information about different birth spacing methods"; 6,000 pamphlets each on "Surgical sterilization", "Postpartum care", "Postabortion care", "Contraceptive methods after delivery"; and 30 copies of the Norms and Procedures for Integral Attention for Women Manual, the MOH's official service delivery guidelines. In addition, 6,000 informed consent forms for IUD insertion and female surgical sterilization were provided

In terms of audiovisual equipment, each hospital was given a television set, a VCR and six different educational videos. Four of the videos provided were developed by the IHSS with support from the INOPAL II Project. The topics presented in the videos were: Reproductive Risk, Prenatal Care, Care for the Newborn and Breastfeeding. The other two videos were about "How to Plan a Family" and "Family Planning Counseling," both produced by AVSC.

\subsection{Supervision and Dissemination of Results}

The project coordinator held quarterly meetings with the technical contacts in each of the participating hospitals. During the meetings, they discussed the latest service statistics, the results of the most recent surveys, the observations made of service delivery activities, and the problems and obstacles to carry out the project activities. The project coordinator functioned as an important link between the different levels of directors in the $\mathrm{MOH}$ and each hospital, which allowed for the quick solution of problems.

As previously mentioned, the results of the baseline, intermediate and endline surveys were discussed in meetings with all the staff in the ob-gyn wards and outpatient 
care. In addition, these results were presented to the regional and national $\mathrm{MOH}$ directors, and the USAID officials during personal visits and through written reports.

\section{MAIN RESULTS}

\subsection{Results from the Baseline Situational Analysis}

Table 4 shows that only the hospitals at La Ceiba, Esperanza and San Felipe in Tegucigalpa offered postpartum/postabortion family planning methods before discharge from the hospital, and that the range of methods offered were limited to the IUD, female sterilization (almost always during cesarean sections) and natural methods. All of the hospitals, except Danli and Juticalpa, reported that the nurses and nurse auxiliaries promoted family planning among postpartum/postabortion patients. However, despite the existence of methods and promotion, all hospitals, except La Ceiba (19\%) and Esperanza (30\%), provided contraceptive methods to less than 5 percent of the women attended for a birth or an abortion complication.

In terms of the providers' perceptions and attitudes, most thought that clients would be grateful if they offered postpartum and postabortion contraceptive methods. They estimated that around one-half of the women would ask for a contraceptive method before discharge from the hospital if they were made available, which showed that the staff was conscious of the high demand for this service. Likewise, the majority of service providers said they were in favor of the establishment of postpartum/postabortion contraceptive services, and thought the majority of their colleagues would support this, but close to one-half were against the assignment of any additional tasks they would have to conduct to achieve this and thought that hiring new staff was the only solution to this problem. However, almost all said they would like to be trained to be able to provide these services. The most negative attitudes regarding the possible establishment of this program were found in the hospitals at Choluteca and Danli, especially among the hospital and ward directors and the Ob-Gyn physicians, who were opposed to receiving training in postpartum/postabortion contraception. In other hospitals, strong biases against specific family planning methods were found, but we thought these could be overcome through training.

In almost all the hospitals, a small proportion of the staff in the Ob-Gyn department had been trained in some aspects of postpartum/postabortion contraception. The topics in which 50 to 70 percent had been trained were: contraceptive methods, family planning counseling, insertion and removal of the IUD, lactational amenorrhea, and natural contraceptive methods. The least common types of training were: sterilization with local anesthesia, vasectomy, administration, supervision, management and control of registration and inventory, where the average percentage of trained hospital staff was below 20 percent. In general terms, more of the service providers in the outpatient ward had family planning training than in the Ob-Gyn wards. When they were asked what type of training they needed, more than one-half of the service providers 
mentioned counseling, hormonal contraceptive methods, IUD insertion and removal, and female sterilization.

The equipment and materials inventory allowed us to determine that, with the exception of the hospitals in Juticalpa and La Esperanza, none of the hospitals had the resources to promote the services and few had the equipment needed for providing IUD insertion and removal services. In fact, only La Ceiba and Santa Rosa de Copan had IUD insertion kits in the puerperium rooms. In the San Felipe hospital, the lack of privacy did not allow for providing these services and only post-placenta IUD insertions were performed. Although all the hospitals had surgery rooms, their equipment was limited, and could not meet the demand for sterilization.

\subsection{Characteristics of the Women Attended}

Women who had been hospitalized for delivery or for an abortion complication were interviewed in the baseline, midterm and endline surveys. In this section, we present the major findings of these surveys not directly related to the supply of information and of services. We found few differences in the values of most dependent variables between the three surveys. For this reason, unless otherwise noted, the results presented in this section are those of the baseline situational analysis. Also, although there are differences between the hospitals, for brevity, we usually only present figures rounded to the nearest whole for the total number of women interviewed in the five hospitals that participated in the study.

\section{Socio-demographic characteristics of the women}

Only 28 percent of the women interviewed in the postpartum period were less than 20 years of age, and 8 percent more than 35 years of age. One-third had been pregnant only once, and 29 percent had had between two and four pregnancies. One-fifth of the women had a paid job outside the home, and 89 percent knew how to read and write. The mean number of years of schooling was 4.5 years and the median was two years of schooling. Eighty-nine percent of the women reported being married or living with a partner.

\section{Quality of care perceptions}

Eighty-nine percent of the women reported having gone to prenatal care during their pregnancy and 75 percent of women went to four or more prenatal care visits. During the baseline survey, only 28 percent of the women said they had received information about family planning during prenatal care visits, but this percentage increased to 43 percent or more in the midterm and endline surveys.

The most important reasons for going to the hospital were its geographical proximity, being the only hospital they know of, and having been referred by friends or health care staff. In 94 percent of the cases, someone accompanied the woman to the hospital, most often her husband (61\%), but also her parents $(17 \%)$, other relatives $(11 \%)$ or friends and neighbors. 
Only around 5 percent of the women reported to have had a problem to be attended or treated. On average, the women waited between five minutes (in La Ceiba) and 104 minutes (in Santa Rosa) to be attended. The most common ways of waiting were: laying on a stretcher $(36 \%)$, walking $(30 \%)$, sitting in a chair $(17 \%)$ or standing $(13 \%)$. It is not common that the service providers introduced themselves by their name with their patients (only in $20 \%$ of the cases). However, service providers often refer to their clients by their name (91\%) and explain what they are going to do before an examination (65\%). However, these explanations seem to be insufficient, since 60 percent of the women would have liked to receive more information. The women were also informed about their health and that of their baby $(77 \%)$ and very few had any doubts remaining about these topics. If we accept the absence of recommendations for improving the service as a good indicator for quality of care, then the hospital that offers the best quality of care is San Felipe, where 91 percent of the women did not have any recommendations, and the hospital with the least quality of care is Santa Rosa de Copan, where 33 percent of the women who answered the endline survey questionnaire did not have recommendations.

\section{Characteristics of pregnancy}

Only a few more than a third of the women were trying to become pregnant when they did so. Fifty-six percent of the women were pleased when they found out they were pregnant, but 38 percent said they would have preferred a pregnancy later, and 5 percent said their pregnancy was unwanted. This last percentage rose to 11 percent in the midterm survey and to 15 percent in the endline survey. Seventeen percent of the women reported having been using a contraceptive method at the time they became pregnant ( $53 \%$ of these were using pills and $18 \%$ periodic abstinence method). In all these cases, the partner knew that the woman was using a contraceptive method and in 90 percent of the cases, the partner agreed with her use of contraception. Fifty-six percent of the women did not want to become pregnant again, and of those women who did, 92 percent wished to become pregnant after waiting two or more years. In conclusion, these data demonstrate a great need for contraceptive methods.

\section{Some data on the women attended for abortion complications}

The women treated for abortion complications were similar to women attended for a delivery. However, these women tended to be slightly older, with a higher number of pregnancies and a larger proportion of single women $(23 \%$ in the endline survey and $27 \%$ in the midterm survey). A large proportion of women worked outside their home $(35 \%)$. Nearly 65 percent of the women did not want to have children in the future.

The questionnaire asked about women's experience with pain. When asked how they graded the pain felt while they waited to be attended (where zero is the absence of pain and 10 the most intense pain), the women reported an average grade of 7, 5 and 6 during the three surveys, respectively. The number of women the service providers asked if they felt pain decreased during the project, and the number of women who received pain medication before the procedure remained the same. In almost all cases, general anesthesia was used, such that no pain was felt during or after the procedure. 
Close to one-fourth of the women interviewed during the three surveys wanted to become pregnant when they did. Approximately 60 percent of the women said they would have preferred not to have become pregnant and a third of the women said they had thought it was good when they became pregnant. A little more than 20 percent of the women reported they had been using a contraceptive method when they became pregnant. The data seem to indicate that at least one-third of these women were treated for complications with a spontaneous abortion.

A section of the questionnaire inquired about partner's participation. A little over 70 percent of the women interviewed in postabortion care reported that their partner knew she had been hospitalized, and of these, more than 70 percent were with her in the hospital. The same proportion of women said they would like their partners to receive information about the treatment she was receiving and more than 80 percent requested that hospital staff explain to her partner the care she would require in the next weeks and about the family planning methods they could use.

\subsection{Results of the Intervention on Services Delivered}

In this section we present the basic indicators used to evaluate the effects of the intervention on the provision of services. Tables 5 to 9 present these indicators.

Table 5 shows that the proportion of women in the postpartum period who received family planning information increased from 43 percent to 87 percent. These women also received more information about each of the different contraceptive methods. The proportion of women who were asked if they wanted a contraceptive method practically doubled, from 42 percent to 82 percent, and the proportion who received a method before discharge from the hospital increased from 10 percent to 33 percent. The mix of methods chosen by the women became more diverse during the duration of the project, decreasing the proportion of women who were sterilized and increasing the proportion who chose other temporary methods. Practically all women reported having themselves made the decision to use a contraceptive method, either alone or talking it over with another person, primarily her partner, but also with health care staff. Table 5 shows that the proportion of women who said they wanted to use a method after delivery remained the same for the duration of the project. However, the proportion of women who wanted to receive a method before discharge from the hospital doubled, from 21 percent to 44 percent. Finally, Table 5 shows that the proportion of women who decided to use a contraceptive method during pregnancy rose from 55 percent to 64 percent, perhaps as a consequence of the training in counseling of providers of prenatal care services in the outlying health centers.

To verify the increase in the provision of postpartum/postabortion contraceptive services, we collected service statistics at the hospitals. As can be observed in Table 6, the proportion of women who had an obstetric event and received a contraceptive method they asked for increased from 6 percent in the July-December 1999 semester to 20 percent in the July-December 2000 semester. The difference between the estimations obtained by the surveys and the service statistics is due to two reasons: the surveys refer to two weeks at the end of the period, while the statistics are an average over a prior 
semester. Also, the service statistics most likely under report the provision of contraceptive methods.

Table 7 shows that the proportion of women who wanted a contraceptive method before discharge from the hospital, but did not receive it (referred to as "unmet need" in this report) decreased from 41 percent to 7 percent. The method most requested and not received was VSC, mainly because this service is not provided on weekends and because it is common for operating rooms to be unavailable during the woman's brief hospital stay. However, Table 7 also shows an indicator for the improvement in quality of care despite this problem in meeting sterilization requests: the proportion of women who were not given an explanation for not receiving the method they had requested decreased from 75 percent to 8 percent.

Table 8 presents the four basic project indicators for each hospital. Both the hospitals that already had established postpartum contraception services, as well as those that introduced the services during the project, made important progresses in informing women, offering the service, providing the methods, and reducing unmet need.

Finally, Table 9 presents the same indicators for the women who were treated for an incomplete abortion. The provision of information was practically universal, and more than half of the women left the hospital with the contraceptive method they had asked for, mainly the injection. The unmet need decreased from 48 percent to 21 percent. This remaining unmet need was also the result of the reduced ability of the hospitals to perform all the female sterilizations requested by women before their discharge from the hospital.

\section{UTILIZATION}

This was a project to expand utilization of the results observed in a previous OR project to five more hospitals. As part of the project, quarterly meetings were held in each hospital with the regional and national program managers and their technical teams to analyze the program's achievements and to agree on future activities. Also, during the last month of the project, the results were presented to regional managers and the staff of the five participating hospitals, as well as to the staff of five new hospitals where the services will soon be introduced. The results will also be presented to the Reproductive Health Working Group, a forum of all the main reproductive health organizations in the country.

USAID has decided to grant funds to EngenderHealth to continue with the expansion of services to five additional hospitals using this model of care. 


\section{CONCLUSIONS AND RECOMMENDATIONS}

The objective of this program was to increase the accessibility to quality postpartum/postabortion contraceptive services and to decrease the unmet need for contraceptive methods during these periods. The results showed that the project was a success in terms of process variables such as provision of information and offering of services, as well as in terms of the proportion of women who adopted a contraceptive method before discharge from the hospital and in the reduction of unmet need (as measured by the number of women who left the hospital without receiving the contraceptive method she wanted).

We believe the success of this study was due to the participative focus in the planning of activities and due to the continuous use of research, which allowed the service providers to focus on the introduction of these services over a long period of time. The presentation of results of the baseline situational analysis in each hospital and the participation of the directors and service providers in the design of strategies to be implemented at their hospitals, was fundamental in creating their commitment towards project activities. In addition, the baseline diagnostic study allowed us to foresee existing difficulties, the hospital training and equipment needs' and the high demand for postpartum/postabortion services. The quarterly surveys provided a valuable opportunity for discussing and solving existing problems and for reestablishing the commitment of project staff towards project goals and activities. In addition, the progress identified in each new survey was an important incentive for service providers. For this reason, we recommend that in future efforts to expand postpartum/postabortion services both the baseline and quarterly survey continue being conducted.

Finally, this project did not initially consider training nurse auxiliaries. However, these agents attend more than half of the deliveries in some hospitals, such that we also recommend that nurse auxiliaries be trained in the delivery of all temporary contraceptive methods, including IUD insertion.

\section{REFERENCES}

Chavez de, A; A. De Romero, V. Ortiz, J. Zelaya, J. Canahuati and J. Townsend. 1986. The promotion of breastfeeding and family planning. Final Technical Report, Proyecto de Apoyo a la Lactancia Materna (PROALMA), Instituto Hondureno de Seguridad Social (IHSS) and the Population Council. Tegucigalpa, D.C., Honduras

Family Health International. Postpartum Contraception: Update on Contraceptive Technology Series. Family Health International, Chapel Hill, N.C., 1995.

Foreit, J., et al. 1993. Acceptability and cost-effectiveness of postpartum contraception 
in Lima, Peru. International Family Planning Perspectives, Vol. 19, No. 1 (March 1993).

Lopez-Canales, J.R., A. Carcamo, J. Galindo, R. Vernon and C. Brambila. 1992, Reproductive Health and Prenatal Care. Final Technical Report. INOPAL II/The Population Council and Instituto Hondureño De Seguridad Social, Tegucigalpa, Honduras, April 1992.

Medina, R; R. Lundgren, and I. Mendoza. 1998. Strengthening of the Postpartum and Postabortion Family Planning Program of the Escuela Hospital. Final Report. Ministry of Health And INOPAL III/Population Council, Tegucigalpa, Honduras, August 1998.

Ministry of Health, ASHONPLAFA, USAID/Honduras and Centers for Disease Control, 1997. Honduras. National Survey of Epidemiology and Family Health 1996 (ENESF 96). Centers for Disease Control, Atlanta. November 1997.

Ministry of Health. 1997. Maternal Mortality Research. Tegucigalpa, Honduras.

Ministry of Health. Norms and Procedures for Integral Attention for Women Manual. Ministry of Health, Honduras. September 1999.

Ministry of Health. Statistical information of hospital care bulletin. Planning and Statistics Department. Ministry of Health, Tegucigalpa, Honduras. 1999.

Ministry of Health. Service Statistics 2000. Obstetrics and Gynecology Department, Escuela Hospital. Ministry of Health, Tegucigalpa, Honduras. 2000.

Shane, B. Family Planning: Saving Women's and Children's Lives; Third Edition Washington, D.C., Population Reference Bureau, January 1997. 


\section{Table 1}

Total number of women interviewed in postpartum and postabortion care, by hospital and type of survey

\begin{tabular}{|c|c|c|c|c|c|c|c|c|c|c|c|c|}
\hline \multirow[t]{2}{*}{ Hospital } & \multicolumn{2}{|c|}{$\begin{array}{l}\text { Baseline } \\
\text { July } 99\end{array}$} & \multicolumn{2}{|c|}{$\begin{array}{l}\text { Monitoring } \\
\text { March } 2000\end{array}$} & \multicolumn{2}{|c|}{$\begin{array}{c}\text { Monitoring } \\
\text { June } 2000\end{array}$} & \multicolumn{2}{|c|}{$\begin{array}{c}\text { Midterm } \\
\text { September } \\
2000\end{array}$} & \multicolumn{2}{|c|}{$\begin{array}{c}\text { Monitoring } \\
\text { December } 2000\end{array}$} & \multicolumn{2}{|c|}{$\begin{array}{c}\text { Endline } \\
\text { March } 2001\end{array}$} \\
\hline & $\mathrm{PP}^{*}$ & $\mathrm{PA}^{* *}$ & PP & PA & PP & PA & PP & PA & PP & PA & PP & PA \\
\hline La Esperanza & 53 & 7 & 45 & 4 & 47 & 13 & 65 & 4 & 38 & 4 & 61 & 3 \\
\hline San Felipe ${ }^{* * *}$ & 109 & 0 & 51 & 0 & 60 & 0 & 120 & 0 & 55 & 0 & 136 & 0 \\
\hline Juticalpa & 100 & 3 & 47 & 3 & 42 & 2 & 170 & 22 & 54 & 7 & 100 & 26 \\
\hline La Ceiba & 107 & 5 & 41 & 9 & 53 & 3 & 133 & 6 & 60 & 8 & 96 & 21 \\
\hline Santa Rosa & 105 & 9 & 38 & 10 & 29 & 6 & 188 & 27 & 56 & 9 & 179 & 21 \\
\hline Total & 474 & 24 & 222 & 26 & 231 & 24 & 675 & 59 & 263 & 28 & 571 & 71 \\
\hline
\end{tabular}


Table 2

Main characteristics and indicators of selected hospitals. Honduras 1999

\begin{tabular}{|c|c|c|c|c|c|c|c|}
\hline Characteristic & $\begin{array}{l}\text { La } \\
\text { Esperanza }\end{array}$ & Danlí & Choluteca & San Felipe & Juticalpa & Ceiba & $\begin{array}{l}\text { Santa } \\
\text { Rosa }\end{array}$ \\
\hline Type of hospital & Area & Regional & Regional & National & Regional & Regional & Regional \\
\hline Total number of beds & 52 & 64 & 147 & 441 & 90 & 118 & 192 \\
\hline Number of ob-gyn beds & 18 & 18 & 33 & 60 & 29 & 25 & 39 \\
\hline $\begin{array}{ll}\text { Services provided } \\
\text { - } & \text { Hospitalization } \\
\text { - } & \text { Eutpatient care } \\
\text { Emergency }\end{array}$ & $\begin{array}{l}4,647 \\
21,397 \\
13,103\end{array}$ & $\begin{array}{l}6,980 \\
57,374 \\
21,213\end{array}$ & $\begin{array}{l}12,277 \\
95,285 \\
30,353\end{array}$ & $\begin{array}{l}10,766 \\
209,017 \\
\text { Not available }\end{array}$ & $\begin{array}{l}10,457 \\
86,603 \\
33,858\end{array}$ & $\begin{array}{l}9,880 \\
66,951 \\
29,863\end{array}$ & $\begin{array}{l}16,437 \\
\text { Not } \\
\text { available } \\
47,525\end{array}$ \\
\hline $\begin{array}{l}\text { Four primary reasons } \\
\text { for hospital visits }\end{array}$ & $\begin{array}{l}\text { Delivery } \\
\text { Pneumonia } \\
\text { Diarrhea } \\
\text { Abortion }\end{array}$ & $\begin{array}{l}\text { Delivery } \\
\text { Abortion } \\
\text { Diarrhea } \\
\text { Maternal } \\
\text { Attention }\end{array}$ & $\begin{array}{l}\text { Delivery } \\
\text { Abortion } \\
\text { B/N* } \\
\text { Diarrhea }\end{array}$ & $\begin{array}{l}\text { Delivery normal } \\
\text { Cervical cancer } \\
\text { C-section } \\
\text { Cataracts }\end{array}$ & $\begin{array}{l}\text { Delivery } \\
\text { Diarrhea } \\
\text { Abortion } \\
\mathrm{B} / \mathrm{N}^{*}\end{array}$ & $\begin{array}{l}\text { Delivery } \\
\text { Abortion } \\
\text { Diarrhea } \\
\mathrm{B} / \mathrm{N}^{*}\end{array}$ & $\begin{array}{l}\text { Delivery } \\
\text { Diarrhea } \\
\text { Pneumonia } \\
\text { Abortion }\end{array}$ \\
\hline $\begin{array}{l}\text { Total number of } \\
\text { deliveries attended }\end{array}$ & 2,949 & 3,224 & 4,677 & 5,188 & 4,639 & 4,379 & 5,919 \\
\hline Normal deliveries & 2,067 & 2,917 & 4,037 & 4,621 & 3,015 & 3,067 & 4,076 \\
\hline Dystostic deliveries & 443 & 7 & 27 & 567 & 918 & 533 & 1,041 \\
\hline C-section rates & 15.0 & 0.2 & 0.6 & 0.1 & 19.8 & 12.2 & 17.6 \\
\hline Abortions & 165 & 387 & 546 & 0 & 440 & 488 & 593 \\
\hline $\begin{array}{l}\text { Human resources } \\
\text { assigned to provide } \\
\text { postobstetric care }\end{array}$ & 32 & 26 & 39 & 123 & 44 & 47 & 50 \\
\hline
\end{tabular}

Source: Statistical information of hospital attention bulletin. Planning and Statistics Department. Ministry of Health, Tegucigalpa, Honduras. Ministry of Health. 1999.

${ }^{*} \mathrm{~B} / \mathrm{N}=$ Bronchopneumonia $\quad$ * Does not provide postabortion care. 


\section{Table 3}

\section{Number of interviews and observations conducted in the baseline situational analysis, by hospital and instrument used}

\begin{tabular}{|c|c|c|c|c|c|c|c|c|}
\hline \multirow{2}{*}{ Instrument } & \multicolumn{8}{|c|}{ Hospital* $^{*}$} \\
\hline & Ceiba & Sur & Danlí & $\begin{array}{l}\text { San } \\
\text { Felipe }\end{array}$ & $\begin{array}{l}\text { Santa } \\
\text { Rosa }\end{array}$ & Juticalpa & $\begin{array}{c}\text { La } \\
\text { Esperanza }\end{array}$ & Total \\
\hline Director interview & 1 & 1 & 1 & 1 & 1 & 1 & 1 & 7 \\
\hline Head of Ob-Gyn interview & 1 & 1 & 1 & 1 & $\mathrm{~N} / \mathrm{A}$ & $\mathrm{N} / \mathrm{A}$ & 1 & 5 \\
\hline $\begin{array}{l}\text { Ob-Gyn service staff } \\
\text { interview }\end{array}$ & 9 & 6 & 5 & 8 & 16 & 6 & 7 & 57 \\
\hline Outpatient staff interview & 10 & 9 & 8 & N/A & $\mathrm{N} / \mathrm{A}$ & 10 & 9 & 46 \\
\hline $\begin{array}{l}\text { Head of Outpatient } \\
\text { services interview }\end{array}$ & 2 & 1 & 2 & N/A & N/A & 2 & 2 & 9 \\
\hline $\begin{array}{l}\text { Equipment and materials } \\
\text { inventory }\end{array}$ & 1 & 1 & 1 & 1 & 1 & 1 & 1 & 7 \\
\hline $\begin{array}{l}\text { Postpartum patient } \\
\text { interviews }\end{array}$ & 107 & 105 & 107 & 110 & 105 & 100 & 53 & 474 \\
\hline $\begin{array}{l}\text { Postabortion patient } \\
\text { interviews }\end{array}$ & 5 & 3 & 10 & $\mathrm{~N} / \mathrm{A}$ & 9 & 3 & 7 & 37 \\
\hline Service observations & 1 & 1 & 1 & 1 & 1 & 1 & 1 & 7 \\
\hline
\end{tabular}

N/A : Not applicable; this staff does not exist in the hospitals visited. 


\section{Table 4}

\section{Family planning services available in the hospitals at the start of the study, according to hospital and type of service}

\begin{tabular}{|c|c|c|c|c|c|c|c|}
\hline \multirow{2}{*}{$\begin{array}{l}\text { Type of family planning service } \\
\text { provided }\end{array}$} & \multicolumn{7}{|c|}{ Hospitals } \\
\hline & Ceiba & Sur & Danlí & $\begin{array}{l}\text { San } \\
\text { Felipe }\end{array}$ & $\begin{array}{c}\text { Santa } \\
\text { Rosa }\end{array}$ & Juticalpa & Esperanza \\
\hline FP Counseling in Outpatient & YES & YES & YES & Does not & Does not & YES & YES \\
\hline FP Methods offered in Outpatient & YES & YES & YES & & have & YES & YES \\
\hline FP Counseling in prenatal care & YES & YES & YES & $\begin{array}{c}\text { Outpatient } \\
\text { Services }\end{array}$ & $\begin{array}{c}\text { Outpatient } \\
\text { Services }\end{array}$ & YES & NO \\
\hline $\begin{array}{l}\text { Staff in charge of promoting } \\
\text { PP/PA Family Planning }\end{array}$ & $\begin{array}{l}\text { Nurse } \\
\text { N Aux** }\end{array}$ & $\begin{array}{l}\text { Nurse } \\
\text { N Aux** }\end{array}$ & NO & $\begin{array}{l}\text { Nurse } \\
\text { N Aux }\end{array}$ & $\begin{array}{c}\text { Nurse } \\
\text { N Aux }\end{array}$ & NO & $\begin{array}{l}\text { Nurse } \\
\text { N Aux } \\
\text { Physician }\end{array}$ \\
\hline $\begin{array}{l}\text { Methods of PP/PA Family } \\
\text { Planning methods before leaving } \\
\text { the hospital * }\end{array}$ & $\begin{array}{l}\text { IUD } \\
\text { FVSC }^{* * *}\end{array}$ & NO & NO & IUD & IUD & NO & $\begin{array}{c}\text { IUD } \\
\text { FVSC } \\
\text { Natural } \\
\text { methods }\end{array}$ \\
\hline $\begin{array}{l}\text { Proportion of PP/PA patients who } \\
\text { leave with a contraceptive method }\end{array}$ & $18.7 \%$ & - & - & $4.6 \%$ & $2.9 \%$ & $5.0 \%$ & $28.3 \%$ \\
\hline
\end{tabular}

* Postabortion patients are not treated in the Maternity ward of San Felipe Hospital

** Auxiliary of Nursing

${ }^{* * *}$ Female voluntary surgical contraception 
Table 5

Indicators of post-partum family planning service delivery, according to survey

\begin{tabular}{|c|c|c|c|}
\hline \multirow{2}{*}{$\begin{array}{l}\text { Indicators of Family Planning services } \\
\text { offered }\end{array}$} & \multicolumn{3}{|c|}{ Survey } \\
\hline & $\begin{array}{l}\text { Baseline } \\
(\mathrm{N}=474)\end{array}$ & $\begin{array}{l}\text { Midterm } \\
(\mathrm{N}=675)\end{array}$ & $\begin{array}{c}\text { Endline } \\
(N=571)\end{array}$ \\
\hline \% who received FP information & $43 \%$ & $69 \%$ & $87 \%$ \\
\hline $\begin{array}{l}\text { Methods mentioned: } \\
\text { - Oral Contraceptives } \\
\text { - Condom } \\
\text { - IUD } \\
\text { - VSC } \\
\text { - Vasectomy } \\
\text { - Injectables }\end{array}$ & $\begin{array}{c}40.4 \% \\
9.9 \% \\
76.8 \% \\
53.7 \% \\
0.5 \% \\
19.2 \%\end{array}$ & $\begin{array}{l}30.2 \% \\
54.6 \% \\
89.9 \% \\
60.6 \% \\
2.6 \% \\
77.1 \%\end{array}$ & $\begin{array}{c}30.3 \% \\
80.6 \% \\
96.6 \% \\
46.5 \% \\
1.2 \% \\
95.8 \%\end{array}$ \\
\hline$\%$ who were asked if they wanted a method & $42 \%$ & $68 \%$ & $82 \%$ \\
\hline $\begin{array}{l}\text { \% who want a method after delivery } \\
\text { (postpartum) }\end{array}$ & $85 \%$ & $80 \%$ & $82 \%$ \\
\hline $\begin{array}{l}\text { When the patient would like to begin using a } \\
\text { FP method: } \\
\text { - Before leaving the hospital } \\
\text { - } 40 \text { days after delivery } \\
\text { - When menstruation begins } \\
\text { - Other }\end{array}$ & $\begin{array}{l}21 \% \\
43 \% \\
14 \% \\
22 \%\end{array}$ & $\begin{array}{c}34 \% \\
45 \% \\
6 \% \\
15 \%\end{array}$ & $\begin{array}{l}44 \% \\
36 \% \\
10 \% \\
10 \%\end{array}$ \\
\hline $\begin{array}{l}\text { When the patient decided to use this method: } \\
\text { - Before the pregnancy } \\
\text { - During the pregnancy } \\
\text { - In the hospital }\end{array}$ & $\begin{array}{l}24 \% \\
55 \% \\
19 \%\end{array}$ & $\begin{array}{l}16 \% \\
58 \% \\
25 \%\end{array}$ & $\begin{array}{l}11 \% \\
64 \% \\
24 \%\end{array}$ \\
\hline$\%$ who received a method during her stay & $10 \%$ & $26 \%$ & $33 \%$ \\
\hline 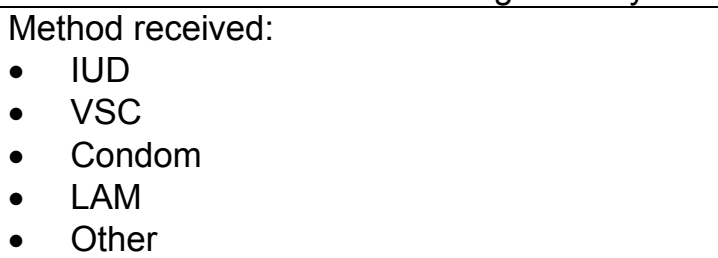 & $\begin{array}{l}44 \% \\
56 \% \\
- \\
- \\
-\end{array}$ & $\begin{array}{l}63 \% \\
24 \% \\
5 \% \\
4 \% \\
4 \%\end{array}$ & $\begin{array}{l}50 \% \\
23 \% \\
10 \% \\
12 \% \\
5 \%\end{array}$ \\
\hline $\begin{array}{l}\text { Person who chose this method: } \\
\text { - Patient } \\
\text { - Patient and someone else }\end{array}$ & $\begin{array}{l}30.1 \% \\
68.7 \%\end{array}$ & $\begin{array}{l}39.2 \% \\
57.7 \%\end{array}$ & $\begin{array}{l}27.6 \% \\
69.0 \%\end{array}$ \\
\hline $\begin{array}{l}\text { \% whose partner is in agreement with the } \\
\text { method used }\end{array}$ & $67.7 \%$ & $50.5 \%$ & $53.5 \%$ \\
\hline
\end{tabular}




\section{Table 6}

Proportion of women who were attended for an obstetric event and who received a contraceptive method, by method and period.

Service statistics of participating hospitals

\begin{tabular}{|c|c|c|c|c|c|c|}
\hline \multirow[b]{2}{*}{ Period } & \multicolumn{4}{|c|}{ Contraceptive Methods } & \multirow[b]{2}{*}{$\begin{array}{l}\text { Total number of } \\
\text { obstetric events }\end{array}$} & \multirow{2}{*}{$\begin{array}{c}\text { Coverage } \\
\%\end{array}$} \\
\hline & IUD & Depo-Provera & VSC & Others & & \\
\hline Jul-Dec 99 & 245 & 254 & 142 & 71 & 11925 & 6.0 \\
\hline Jan-Jun 00 & 809 & 555 & 248 & 117 & 11704 & 14.8 \\
\hline Jul-Dec 00 & 1183 & 851 & 359 & 173 & 12725 & 20.2 \\
\hline
\end{tabular}


Table 7

Indicators of unmet need, according to survey

\begin{tabular}{|c|c|c|c|}
\hline \multirow[t]{2}{*}{ Indicators of unmet need } & \multicolumn{3}{|c|}{ Survey } \\
\hline & $\begin{array}{l}\text { Baseline } \\
(N=426)\end{array}$ & $\begin{array}{l}\text { Midterm } \\
(\mathrm{N}=493)\end{array}$ & $\begin{array}{l}\text { Endline } \\
(\mathrm{N}=386)\end{array}$ \\
\hline $\begin{array}{l}\% \text { who would like to receive a method but } \\
\text { did not receive it }\end{array}$ & $41 \%$ & $15 \%$ & $7 \%$ \\
\hline $\begin{array}{l}\text { Method desired but not received: } \\
\text { - } \quad \text { Oral contraceptives } \\
\text { - } \quad \text { Progestyn only pills } \\
\text { - } \quad \text { IUD } \\
\text { - } \quad \text { VSC } \\
\text { - Injectables } \\
\text { - Other } \\
\text { - } \quad \text { Does not know }\end{array}$ & $\begin{array}{c}14 \% \\
1 \% \\
23 \% \\
31 \% \\
12 \% \\
12 \% \\
7 \%\end{array}$ & $\begin{array}{l}7 \% \\
3 \% \\
8 \% \\
68 \% \\
11 \% \\
3 \% \\
1 \%\end{array}$ & $\begin{array}{c}- \\
- \\
25 \% \\
75 \% \\
- \\
-\end{array}$ \\
\hline $\begin{array}{l}\% \text { who were not explained why they were } \\
\text { not given a method }\end{array}$ & $74.9 \%$ & $18.4 \%$ & $7.7 \%$ \\
\hline
\end{tabular}




\section{Table 8}

\section{Indicators of family planning service delivery and unmet need, according to hospital and survey}

\begin{tabular}{|c|c|c|c|}
\hline \multirow[b]{2}{*}{$\begin{array}{c}\text { Indicators of family planning service delivery } \\
\text { and unmet need }\end{array}$} & \multicolumn{3}{|c|}{ Survey } \\
\hline & $\begin{array}{c}\text { Baseline } \\
\text { July/99 }\end{array}$ & $\begin{array}{l}\text { Midterm } \\
\text { Sep/00 }\end{array}$ & $\begin{array}{c}\text { Endline } \\
\text { March/01 }\end{array}$ \\
\hline $\begin{array}{l}\text { \% of women who leave with a family planning method } \\
\text { - Juticalpa } \\
\text { - Santa Rosa } \\
\text { - } \text { Ceiba } \\
\text { - Sa Esperanza } \\
\text { - San Felipe }\end{array}$ & $\begin{array}{c}5 \% \\
3 \% \\
19 \% \\
30 \% \\
4 \%\end{array}$ & $\begin{array}{l}14 \% \\
18 \% \\
27 \% \\
79 \% \\
30 \%\end{array}$ & $\begin{array}{l}25 \% \\
29 \% \\
41 \% \\
72 \% \\
20 \%\end{array}$ \\
\hline $\begin{array}{l}\text { \% of women who received family planning information } \\
\text { - Juticalpa } \\
\text { - Santa Rosa } \\
\text { - } \quad \text { Leiba Esperanza } \\
\text { - San Felipe }\end{array}$ & $\begin{array}{l}23 \% \\
40 \% \\
76 \% \\
55 \% \\
25 \%\end{array}$ & $\begin{array}{c}75 \% \\
60 \% \\
72 \% \\
100 \% \\
58 \%\end{array}$ & $\begin{array}{l}96 \% \\
78 \% \\
92 \% \\
97 \% \\
85 \%\end{array}$ \\
\hline $\begin{array}{l}\text { \% of women who were offered a family planning method } \\
\text { - Juticalpa } \\
\text { - Santa Rosa } \\
\text { - } \text { Ceiba } \\
\text { - Sa Esperanza } \\
\text { San Felipe }\end{array}$ & $\begin{array}{l}2 \% \\
42 \% \\
69 \% \\
60 \% \\
27 \%\end{array}$ & $\begin{array}{c}67 \% \\
62 \% \\
70 \% \\
100 \% \\
56 \%\end{array}$ & $\begin{array}{c}90 \% \\
79 \% \\
92 \% \\
95 \% \\
67 \%\end{array}$ \\
\hline $\begin{array}{l}\text { Unmet need (women who wanted to receive a family } \\
\text { planning method at the hospital but did not receive it) } \\
\text { - Juticalpa } \\
\text { - Santa Rosa } \\
\text { - Ceiba } \\
\text { - La Esperanza } \\
\text { - San Felipe }\end{array}$ & $\begin{array}{l}46 \% \\
34 \% \\
50 \% \\
24 \% \\
42 \%\end{array}$ & $\begin{array}{c}10 \% \\
8 \% \\
28 \% \\
0 \% \\
26 \%\end{array}$ & $\begin{array}{c}16 \% \\
0 \% \\
18 \% \\
0 \% \\
4 \%\end{array}$ \\
\hline
\end{tabular}




\section{Table 9}

Indicators of postabortion contraception service delivery, according to survey

\begin{tabular}{|c|c|c|c|}
\hline \multirow{2}{*}{$\begin{array}{l}\text { Indicators of postabortion } \\
\text { contraception service delivery }\end{array}$} & \multicolumn{3}{|c|}{ Survey } \\
\hline & $\begin{array}{l}\text { Baseline } \\
(\mathrm{N}=24)\end{array}$ & $\begin{array}{l}\text { Midterm } \\
(\mathrm{N}=59)\end{array}$ & $\begin{array}{l}\text { Endline } \\
(\mathrm{N}=71)\end{array}$ \\
\hline \% who received FP information & $17 \%$ & $80 \%$ & $85 \%$ \\
\hline$\%$ who received a method during her stay & $13 \%$ & $34 \%$ & $54 \%$ \\
\hline $\begin{array}{l}\text { Method received } \\
\text { - IUD } \\
\text { - } \text { VSC } \\
\text { - Condom } \\
\text { - OCs } \\
\text { - Injectable }\end{array}$ & $\begin{array}{c}- \\
100 \% \\
- \\
- \\
-\end{array}$ & $\begin{array}{c}25 \% \\
5 \% \\
- \\
10 \% \\
60 \%\end{array}$ & $\begin{array}{c}3 \% \\
3 \% \\
5 \% \\
11 \% \\
79 \%\end{array}$ \\
\hline $\begin{array}{l}\% \text { who wanted a method but did not } \\
\text { receive it (unmet need) }\end{array}$ & $48 \%$ & $18 \%$ & $21 \%$ \\
\hline
\end{tabular}




\section{APPENDICES}

Appendix 1: Instruments used for surveys.

Appendix 2: Questionnaires used for monitoring. 